\title{
Atmospheric emission inventory of the Maurienne valley for an atmospheric numerical model
}

\author{
Guillaume Brulfert ${ }^{\mathrm{a}, *}$, Jean-Pierre Chollet ${ }^{\mathrm{a}}$, Bernard Jouve ${ }^{\mathrm{b}}$, Hervé Villard ${ }^{\mathrm{b}}$ \\ ${ }^{a}$ Laboratory of Geophysical and Industrial Fluid Flows (University J. Fourier, INP Grenoble, CNRS), BP53, 38041 Grenoble Cedex, France \\ b Air de l'Ain et des Pays de Savoie, Air Quality Agency, 430 rue de la Belle Eau, Z.I. Landiers Nord, 73000 Chambe'ry, France
}

Within the framework of an air quality study of the French alpine valleys (POVA program), an atmospheric emission inventory concerning major pollutants: $\mathrm{CO}, \mathrm{NOx}, \mathrm{SO}_{2}, \mathrm{CH}_{4}$, particles (PT) and non-methane volatile organic compounds (NMVOC) was carried out. This inventory has a spatial resolution of $1 \mathrm{~km}^{2}$ and was established for the reference year 2003.

The coexistence of economic activities and the Vanoise national park makes the Maurienne valley a sensitive site, particularly representative of the problems of sustainable development in alpine areas, where air pollution is one of the most important aspects.

The area, which covers $4588 \mathrm{~km}^{2}$, is an alpine valley that is sensitive to air pollution due to the emission sources (traffic, industries, private heating, etc.), its morphology (a narrow valley surrounded by high ranges), and local meteorology (temperature inversions and slope winds).

As expected, the result which includes both biogenic and anthropogenic sources shows serious emissions of pollutants that are mainly due to the presence of highways and industries around. Two emission inventories were drawn up: one with emission factors determined by CORINAIR (from the European Environment Agency) and the other with emission factors determined by BUWAL-OFEFP (from Swiss Agency for the Environment, Forests and Landscape). The inventories were then compared thanks to concentrations calculated from a numerical model. Computations were run for an intensive field observation period from 25 June to 2 July 2003.

Keywords: Atmospheric emission inventory; Emission factors; Hourly variation of emissions; Non-methane volatile organic compounds (NMVOC); Photochemistry model

* Corresponding author. Tel.: +334768250 75; fax: +33476 827022.

E-mail address: guillaume.brulfert@hmg.inpg.fr (G. Brulfert).

\section{Introduction}

Air pollution modelling is a powerful tool capable of assisting policy makers in developing abatement strategies to reduce pollutant emissions and improve 
air quality. One of the most crucial data sets needed to initiate chemical and photochemical reaction mechanisms included in the model is the emission inventory. In fact, the precision with which the emission scenario is generated can be considered as one of the major limiting factors in performing valid simulations of the emission fields for primary and secondary pollutants.

Since the beginning of the 1980s, a number of anthropogenic and biogenic emission inventories have been carried out, mainly in the most industrialized countries. These inventories generally cover large areas like Europe (OECD, 1984; Veldt, 1991; Lenhart and Friedrich, 1995) or the United States (Voldner et al., 1980; Clark, 1980; Lamb et al., 1987, 1993) and are used to perform large-scale transport modelling. More recently, other modelling programs have focused on pollutant dispersion and ozone emission at regional or more local scales (Ponche et al., 1998, 2000; Khatami et al., 1998; Cros et al., 2004), most of them using the CORINAIR methodology (e.g. Aleksandropoulou and Lazaridis, 2004). There are also emission inventories for air quality modelling in mountainous areas but in valleys significantly broader than the Maurienne (Sturm et al., 1999; Couach et al., 2003).

There is now a growing concern over the impact of atmospheric pollution on public health. Following the accident in the Mont-Blanc tunnel on 24 March 1999, (France). The heavy-duty traffic (about 2130 trucks per day) was diverted to the Maurienne valley, with up to 4250 trucks per day. Within the framework of the Pollution in Alpine Valleys project (Jaffrezo et al., 2005) measurement campaigns were undertaken for several one week periods. Modelling in POVA should help to explain the process leading to episodes of atmospheric pollution, both in summer and in winter. The general topics of the program are comparative studies of air quality and the modelling of atmospheric emissions and transport in these two French alpine valleys before and after the reopening of the tunnel to heavy-duty traffic in order to identify the sources and characterize the dispersion of pollutants. The program combines 3D modelling with field campaigns in order to study the impact of traffic and local development scenarios.

Bottom-up and top-down methodologies are combined (depending on available data) to map emissions with a yearly resolution. The emissions are then distributed for modelling at the hourly level by taking account of the season and the day of the week. The corresponding software was designed in order to update the emission inventory as easily as possible. Changes in pollution may therefore be documented year after year. Abatement scenarios may be built by appropriately changing total vehicle characteristics, traffic and industrial activities. It is also easy to update emission factors whose values are expected to be improved in the future thanks to better knowledge of emissions.

After a description of the Maurienne valley, we discuss the preparation of two inventories with emission factors from CORINAIR and OFEFP: species, spatialisation methodology and emission sources. The two inventories are then used and after disintegration (with time and according to chemical species), the results from the photochemical model are analysed by comparing them with the measurements from the summer 2003 intensive period of POVA observations.

The Maurienne valley differs noticeably from sites considered in most emission inventory studies, where urban contributions are significant. Because of the narrowness of the valley, sources have to be described at a fairly short length-scale. Inhabitants and industrial activities are concentrated in limited areas along the bottom of the valley. A large part of the domain of interest is covered with forests and pastures.

Finally, results from an air quality model of the Maurienne valley are considered since the emission inventory is designed to be used as an input to such a model and the emission fluxes cannot be compared with measurements, in contrast to concentrations computed from modelling to be examined side by side with POVA data.

\section{The Maurienne valley emission inventory}

\subsection{Area of interest}

The Maurienne valley $(130 \mathrm{~km})$ is a typical arcshaped (Fig. 1) alpine and mountainous area located along the border between France and Italy. The general orientation of the valley (after Saint Jean de Maurienne) is roughly West-East. The entrance is wide and the valley is closed at its East end by the Mont Cenis pass at $2081 \mathrm{~m}$ a.s.l. (to Italy). The altitude of the bottom of the valley increases progressively from Saint Jean de 


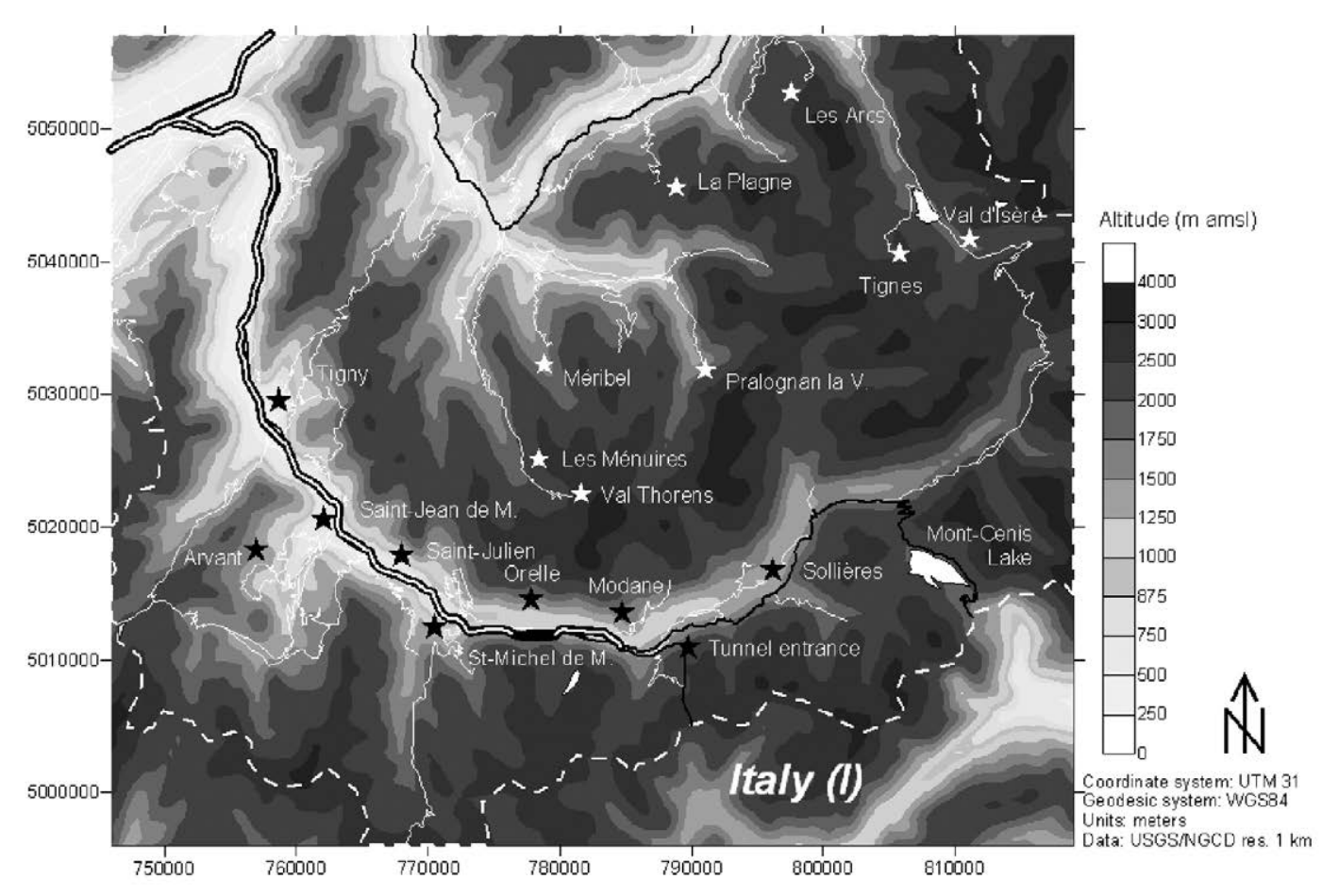

Fig. 1. Maurienne valley. Black stars indicate measurement sites and white stars ski resorts. The Vanoise national park (peripheral and central zone) extends from a line across Méribel-Val-Thorens, Modane to the east of the domain.

Maurienne (550 $\mathrm{m}$ a.s.1.) to Sollières (1340 $\mathrm{m}$ a.s.1.). Its width varies from a few tens of metres at Orelle to $3 \mathrm{~km}$ at Sollières.

The center of the area $\left(45.33^{\circ} \mathrm{N}, 6.6^{\circ} \mathrm{E}\right)$ is at approximately $150 \mathrm{~km}$ from Lyons (France) and from Geneva (Switzerland) and $100 \mathrm{~km}$ from Turin (Italy).

Sixty-three municipalities lie in the valley from Aiton to the Iseran pass, with 42,000 inhabitants (INSEE, data from 1999 census). The largest towns are:

- Saint Jean de Maurienne: 15,666 inhabitants.

- Saint Michel de Maurienne: 5670 inhabitants.

- Modane: 6547 inhabitants.

The population density is 44 inhabitants per $\mathrm{km}^{2}$. A large part of the population lives in the bottom of the valley, where most economic activities (including industries and main roads) are located. Eighty percent of the labour force works in service industries, $15 \%$ in industries and $5 \%$ in agriculture. Thirteen hundred employees work in the metal- lurgical industries and more than 300 employees in chemicals. The road network is developing thanks to some twenty ski resorts and the connecting passage to Italy via the Fréjus tunnel (RN6 main road, A43 highway). One year after the Mont-Blanc tunnel was closed, road traffic had doubled, with 8000 vehicles per day, including 5000 heavy vehicles.

Road traffic is not the only reason for air quality problems in the valley: industrial plants are located around 3 main places:

- ELF-ATOCHEM: phosphor chemistry at Epierre (25 km from Saint Jean de Maurienne towards Tigny) and amine synthesis and organic solvents at La Chambre (13 km from Saint Jean de Maurienne towards Tigny).

- PECHINEY: aluminium chemistry (Saint Jean de Maurienne).

- METALTEMPLE: smelting works (Saint Michel de Maurienne). 
Vegetation is relatively dense (Fig. 2). The mountain slopes are devoted to residual agriculture and above all full nature tourism activities. The Vanoise national park (peripheral and central zones) extends from a line across Méribel, Val-Thorens and Modane to the east of the domain; it was the first French park to be created, in 1963. This duality makes the Maurienne valley a sensitive site, particularly representative of the problems of sustainable development in alpine areas, with air quality as an important challenge.

\subsection{Reference year and spatial resolution of the emission inventory}

The year 2003 was chosen as reference year and all the data gathered in order to build the emission inventory are related to this period. However, when data were missing for this time span, those from the year 2001 were used. Considering the domain for modelling air quality $(74 * 62 \mathrm{~km})$, the spatial resolution was chosen to be $1 \mathrm{~km}$ in order to be the same as that of the chemistry model in ' 4.1 Simulation model'. One of the primary tasks was to locate all the emission sources and to determine the spatial emission distributions in order to draw up emission maps for each species or group of compounds, for different time resolutions (yearly or hourly emissions). This was achieved by using Geographic Information Systems (GIS). These GIS were also used to determine the land use and geographic coverage of the domain.

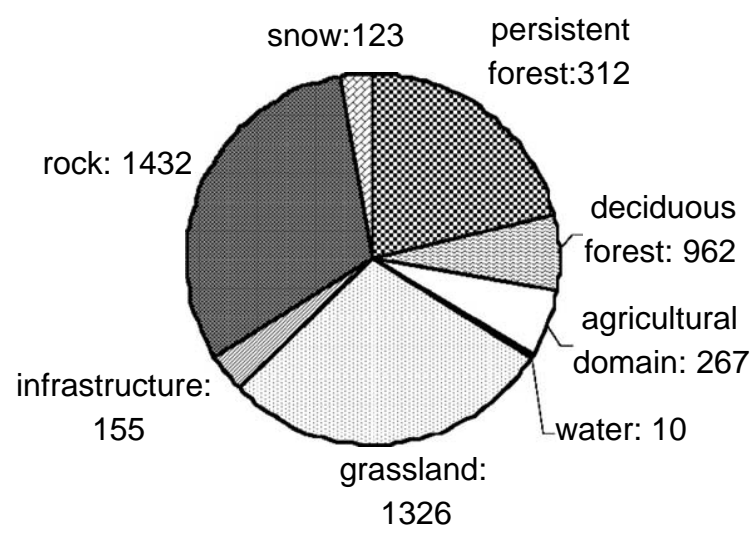

Fig. 2. Land use in the Maurienne valley $\left(\mathrm{km}^{2}\right)$.

\subsection{The different species of the emission inventory}

All the major compounds emitted both by anthropogenic and natural sources (mainly forests and grassland) are considered. They are necessary and sufficient to model atmosphere chemistry. The emission inventory of anthropogenic and biogenic emissions of NOx and NMVOC makes it possible to model ozone chemistry at mesoscale. Emissions from anthropogenic sources mainly result from the use of different types of fossil fuel and from solvent evaporation. The levels and composition of these emissions depend on several main parameters such as combustion processes, temperature, filtration devices etc. (combustion) and on the conditions of use and recovering procedures, when they exist (solvents). Finally, the compounds in our emission inventory are: sulphur dioxide $\left(\mathrm{SO}_{2}\right)$, nitrogen oxides ( $\mathrm{NOx}$ ), carbon monoxide $(\mathrm{CO})$, methane $\left(\mathrm{CH}_{4}\right)$, non-methane volatile organic compounds (NMVOC) and particles. Contrary to most emission inventories, methane is explicitly considered since it is a precursory gas of ozone when NOx concentration and solar exposure are high enough. The NMVOC come both from natural (vegetation) and anthropogenic sources. Due to the wide range of volatile organic compounds (VOC) emitted, individual species cannot be taken into account. Disintegration of VOC for the purpose of modelling will be explained in section ' 4.2 NMVOC disintegration for RACM'. Particles are not yet taken into account in chemistry modelling.

\subsection{Spatial distribution of emissions}

The main problem arising in such a study is due to the need to collect a very large number of data of many different origins, which are organized in quite different ways. Data come from different levels: national, regional and local administrations and offices, and private and public companies for some particular sources. Primary data generally correspond to activity measurement associated with road traffic, private heating and industrial production. In order to be used as an input for the atmosphere chemistry model, they have to be processed to produce species mass fluxes. The methodology for spatialisation proposed and developed in several emission inventories (Ponche, 1992; Ponche et al., 
1993, 1995; Khatami et al., 1998) is summarized in Fig. 3.

\subsection{Classification of emission sources}

The classification includes both natural and anthropogenic sources. Although anthropogenic sources represent the major part of atmospheric emissions, natural sources cannot be ignored, especially when their contributions to NMVOC emissions are considered. The sources were split into 4 main categories, according to their origins:

- Biogenic emission sources, which include emissions from forests and grassland (NMVOC).

- Emissions from the service sector, which include emissions from public and private administrations and services (hospitals, public offices, etc.) where there is energy consumption. The contribution of private housing (heating, warm water production) is taken into account.
- Emissions due to transport, which include road traffic (light and heavy vehicles, motorbikes) out of and in the towns.

- Emissions due to industrial activities.

Whereas the above classification was used mostly for data collection, the emission inventory was built by considering a different classification based on the geometrical characteristics of the different types of sources. In this way, we distinguished three types of source:

- Point sources: large amounts of pollutants are emitted from very small and well-located areas (small factories, boilers, gas stations).

- Line sources: these take into account emissions from road traffic.

- Surface sources: these include all sources which are not included in the two previous categories (forest, grassland, large factories, use of solvents by the population).

1. Inventory of emission sources: $\mathrm{CO}, \mathrm{NOx}, \mathrm{SO}_{2}, \mathrm{NMVOC}, \mathrm{CH}_{4}$
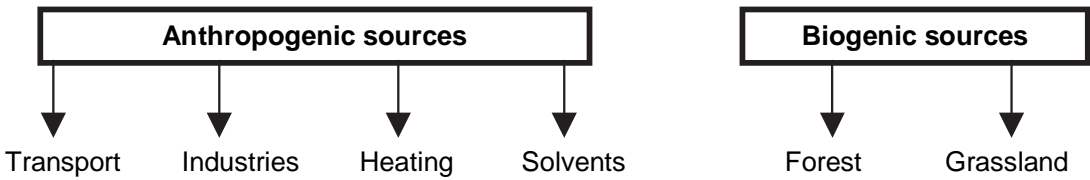

\section{Cartographic features of the area}

- Administrative and geographical boundaries

- Topography, land use

- Locations of the atmospheric emissions: point, line and surface sources

\section{Gridding of the area}

- Choice of the gridding area $(74 \times 62$ $\mathrm{km}^{2}$ )

- Spatial resolution $\left(1 \mathrm{~km}^{2}\right)$

- Geographical coordinates (UTM 31)

4. Spatial distribution per pollutant of the emissions

- For the different source types

- For the sum of different emission contributions

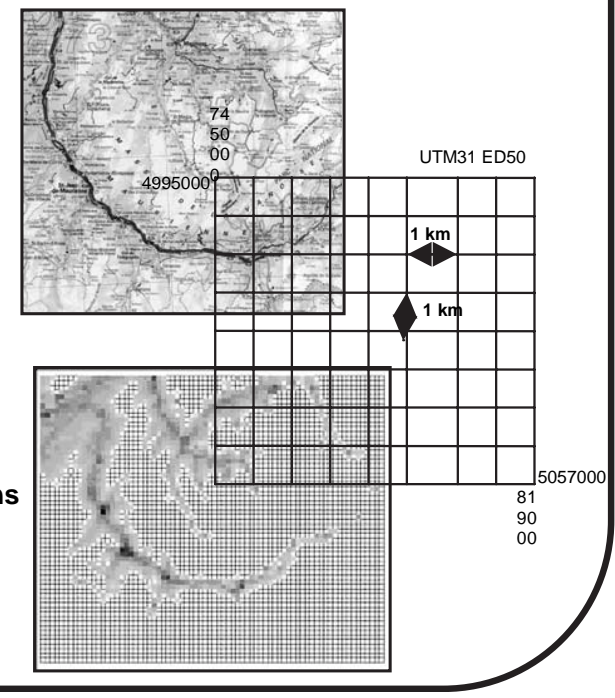

Fig. 3. Methodology for the spatialisation of atmospheric emissions. 
Table 1

Classes of the emission inventory with corresponding SNAP code

\begin{tabular}{lllll}
\hline Anthropogenic sources & \multicolumn{3}{c}{ Biogenic sources } \\
\hline Point and area sources & \multicolumn{3}{c}{ Road transport sources } \\
\hline Commercial boiler & 020103 & Heavy vehicles & 070300 & Forest \\
Residential boiler & 020202 & Light vehicles & 070100 & Grassland \\
Domestic solvent & 060408 & Motorbikes & 070500 & 110200 \\
Industries & 030103 & & & \\
\hline
\end{tabular}

All the classes of the emission inventory are given in Table 1. There is considerable rail traffic in the valley but it does not contribute to emissions since the lines are electrified.

\subsection{Source evaluation method}

\subsubsection{Heating emissions}

The heating of housing and industries as well as the production of hot water contribute to the emission of pollutants. Inhabitants and industries in the valley mainly use fuel oil. The emissions from heating were spatially distributed within the population (INSEE data from 1999 census).

\subsubsection{Domestic solvent emissions}

Emissions of domestic NMVOC (mostly solvents) are very difficult to estimate. Each person is a potential emission source; the CORINAIR (CORINAIR, 2003) gives an emission level of $2.6 \mathrm{~kg} /$ year/inhabitant and the OFEFP $1.1 \mathrm{~kg} /$ year/ inhabitant. The emissions were then distributed spatially within the population (INSEE data from 1999 census).

\subsubsection{Industrial emissions}

All the major stationary combustion and production installations are considered in this category. The point sources are defined according to the levels of $\mathrm{SO}_{2}$, NOx and VOC emissions or according to energy consumption. In France, point sources have been listed by the authorities to recover taxes on

Table 2

Typical speed range of vehicles

\begin{tabular}{llll}
\hline & Urban & Rural & Highway \\
\hline $\begin{array}{l}\text { Typical speed range } \\
\left(\mathrm{km} \mathrm{h}^{-1}\right)\end{array}$ & $10-50$ & $40-80$ & $70-130$ \\
\hline
\end{tabular}

$\mathrm{SO}_{2}$ and $\mathrm{NOx}$ emissions. Therefore these large emission sources are generally well identified and located.

\subsubsection{Traffic emissions}

Road traffic is one of the most significant anthropogenic sources of NOx and NMVOC. To perform this part of the emission inventory, we had to make several assumptions according to the characteristics of the traffic. Two types of traffic are distinguished: urban and non-urban. Outside the towns, all the roads were considered as line emission sources, while in the towns, due to the dense network of streets, these were classified as surface sources. Even vehicles were divided into several categories according to their weight and engine type. Table 2 shows that average speeds are adapted to the type of road (COPERT III, 2001).

To determine traffic intensity, official vehicle figures from the 'Direction Départementale de l'Equipement de la Savoie' and 'Société Française du Tunnel Routier du Fréjus' (highway traffic figures) were used. Records are available at each exit from the highway, and along the main road (5 recording places). Data from the INSEE were used to describe urban traffic. This national institute reckons that every inhabitant over 6 years old makes an $8.7 \mathrm{~km}$ journey three times per day. The emissions were then spatially distributed within the population.

The emission inventory adjusts emissions to the road gradient with COPERT III software (COPERT

Table 3

Tonnage of heavy vehicles involved in the cross-border transit traffic

\begin{tabular}{llll}
\hline Tons & $16>\mathrm{HV}$ & $16<\mathrm{HV}<32$ & $\mathrm{HV}>32$ \\
Percent of vehicles & 0 & 10.43 & 89.57
\end{tabular}


Table 4

Emission factors (g/GJ) from CORINAIR methodology

\begin{tabular}{|c|c|c|c|c|c|c|c|c|c|c|}
\hline Snap1 & Snap2 & Snap3 & NAPFUE code & Fuel & $\mathrm{CO}$ & VOC & NOx & $\mathrm{SO}_{2}$ & $\mathrm{PM}$ & $\mathrm{CH}_{4}$ \\
\hline 02 & 01 & 03 & 101 & Charcoal grey & 4800 & 50 & 50 & 550 & 439 & 450 \\
\hline 02 & 01 & 03 & 111 & Wood & 5790 & 480 & 50 & 48.39 & 1558 & 320 \\
\hline 02 & 01 & 03 & 203 & Heavy fuel & 13 & 2.1 & 98 & 1470 & 58.7 & 10 \\
\hline 02 & 01 & 03 & 204 & Fuel & 43 & 1.5 & 47 & 141 & 3.6 & 3.5 \\
\hline 02 & 01 & 03 & 301 & Natural gas - city gas & 250 & 2.5 & 46 & 0 & 6.7 & 2.5 \\
\hline 02 & 01 & 03 & 303 & Gas & 53 & 3.5 & 69 & 0 & 2 & 1.5 \\
\hline 02 & 02 & 02 & 101 & Charcoal grey & 4800 & 50 & 50 & 550 & 439 & 450 \\
\hline 02 & 02 & 02 & 111 & Wood & 5790 & 480 & 50 & 48.39 & 1558 & 320 \\
\hline 02 & 02 & 02 & 203 & Heavy fuel & 13 & 2.1 & 98 & 1470 & 58.7 & 10 \\
\hline 02 & 02 & 02 & 204 & Fuel & 43 & 1.5 & 47 & 141 & 3.6 & 3.5 \\
\hline 02 & 02 & 02 & 301 & Natural gas-city gas & 250 & 2.5 & 46 & 0 & 6.7 & 2.5 \\
\hline 02 & 02 & 02 & 303 & Gas & 53 & 3.5 & 69 & 0 & 2 & 1.5 \\
\hline 06 & 04 & 08 & 888 & Solvents & 0 & 2590 & 0 & 0 & 0 & 0 \\
\hline 03 & 01 & 03 & 101 & Charcoal grey & 73 & 50 & 155 & 550 & 439 & 511 \\
\hline 03 & 01 & 03 & 107 & Coke & 5500 & 225 & 323 & 550 & 439 & 200 \\
\hline 03 & 01 & 03 & 108 & Coal & 5500 & 225 & 323 & 550 & 439 & 200 \\
\hline 03 & 01 & 03 & 111 & Wood & 627 & 480 & 206 & 48.39 & 1558 & 601 \\
\hline 03 & 01 & 03 & 203 & Heavy fuel & 10 & 34 & 165 & 1470 & 58.7 & 10 \\
\hline 03 & 01 & 03 & 204 & Fuel & 10 & 1.5 & 70 & 141 & 3.6 & 19 \\
\hline 03 & 01 & 03 & 301 & Natural gas-city gas & 10 & 2.5 & 62 & 0 & 6.7 & 2.5 \\
\hline 03 & 01 & 03 & 303 & Gas & 250 & 3.14 & 105 & 0 & 2 & 6 \\
\hline
\end{tabular}

III, 2001). The types of vehicles on the road in the valley are not representative of the average national situation. With data from COPERT III (Bourdeau, 1998) the emissions are adapted to road figures in the valley by the air quality agency 'Air de l'Ain et des Pays de Savoie'. Light vehicles have the same characteristics as those nationwide but the proportion of vehicles over 32 tons is very high because

Table 5

Emission factors (g/GJ) from OFEFP methodology

\begin{tabular}{|c|c|c|c|c|c|c|c|c|c|c|}
\hline Snap1 & Snap2 & Snap3 & NAPFUE code & Fuel & $\mathrm{CO}$ & VOC & NOx & $\mathrm{SO}_{2}$ & $\mathrm{PM}$ & $\mathrm{CH}_{4}$ \\
\hline 02 & 01 & 03 & 101 & Charcoal grey & 3500 & 100 & 65 & 350 & 150 & 300 \\
\hline 02 & 01 & 03 & 111 & Wood & 2600 & 40 & 100 & 20 & 50 & 120 \\
\hline 02 & 01 & 03 & 203 & Heavy fuel & 15 & 4 & 170 & 480 & 23 & 4 \\
\hline 02 & 01 & 03 & 204 & Fuel & 20 & 8 & 59 & 66 & 0.3 & 2 \\
\hline 02 & 01 & 03 & 301 & Natural gas - city gas & 49 & 2 & 30 & 0.5 & 0.2 & 6 \\
\hline 02 & 01 & 03 & 303 & Gas & 49 & 2 & 30 & 0.5 & 0.2 & 6 \\
\hline 02 & 02 & 02 & 101 & Charcoal grey & 3500 & 100 & 65 & 350 & 150 & 300 \\
\hline 02 & 02 & 02 & 111 & Wood & 2600 & 40 & 100 & 20 & 50 & 120 \\
\hline 02 & 02 & 02 & 203 & Heavy fuel & 15 & 4 & 170 & 480 & 23 & 4 \\
\hline 02 & 02 & 02 & 204 & Fuel & 20 & 8 & 59 & 66 & 0.3 & 2 \\
\hline 02 & 02 & 02 & 301 & Natural gas - city gas & 49 & 2 & 30 & 0.5 & 0.2 & 6 \\
\hline 02 & 02 & 02 & 303 & Gas & 49 & 2 & 30 & 0.5 & 0.2 & 6 \\
\hline 06 & 04 & 08 & 888 & Solvents & 0 & 1070 & 0 & 0 & 0 & 0 \\
\hline 03 & 01 & 03 & 101 & Charcoal grey & 100 & 9 & 250 & 500 & 50 & 9 \\
\hline 03 & 01 & 03 & 107 & Coke & 100 & 9 & 250 & 500 & 50 & 9 \\
\hline 03 & 01 & 03 & 108 & Coal & 100 & 9 & 250 & 500 & 50 & 9 \\
\hline 03 & 01 & 03 & 111 & Wood & 650 & 7 & 140 & 20 & 80 & 21 \\
\hline 03 & 01 & 03 & 203 & Heavy fuel & 15 & 4 & 170 & 480 & 23 & 4 \\
\hline 03 & 01 & 03 & 204 & Fuel & 15 & 4 & 170 & 480 & 23 & 4 \\
\hline 03 & 01 & 03 & 301 & Natural gas - city gas & 14 & 2 & 47 & 0.5 & 0.2 & 6 \\
\hline 03 & 01 & 03 & 303 & Gas & 14 & 2 & 47 & 0.5 & 0.2 & 6 \\
\hline
\end{tabular}


Table 6

Absolute value of the relative difference (\%) between the emission factors from CORINAIR and OFEFP methodologies

\begin{tabular}{|c|c|c|c|c|c|c|c|c|c|c|}
\hline$\underline{\text { Snap1 }}$ & Snap2 & Snap3 & NAPFUE code & Fuel & $\mathrm{CO}(\%)$ & VOC $(\%)$ & NOx $(\%)$ & $\mathrm{SO}_{2}(\%)$ & PM (\%) & $\mathrm{CH}_{4}(\%)$ \\
\hline 02 & 01 & 03 & 101 & Charcoal grey & 27 & 100 & 30 & 36 & 65 & 33 \\
\hline 02 & 01 & 03 & 111 & Wood & 55 & 91 & 100 & 58 & 96 & 62 \\
\hline 02 & 01 & 03 & 203 & Heavy fuel & 15 & 90 & 73 & 67 & 60 & 60 \\
\hline 02 & 01 & 03 & 204 & Fuel & 53 & 433 & 25 & 53 & 91 & 42 \\
\hline 02 & 01 & 03 & 301 & Natural gas - city Gas & 80 & 20 & 34 & 0 & 97 & 140 \\
\hline 02 & 01 & 03 & 303 & Gas & 7 & 42 & 56 & 0 & 90 & 300 \\
\hline 02 & 02 & 02 & 101 & Charcoal grey & 27 & 100 & 30 & 36 & 65 & 33 \\
\hline 02 & 02 & 02 & 111 & Wood & 55 & 91 & 100 & 58 & 96 & 62 \\
\hline 02 & 02 & 02 & 203 & Heavy fuel & 15 & 90 & 73 & 67 & 60 & 60 \\
\hline 02 & 02 & 02 & 204 & Fuel & 53 & 433 & 25 & 53 & 91 & 42 \\
\hline 02 & 02 & 02 & 301 & Natural gas - city gas & 80 & 20 & 34 & 0 & 97 & 140 \\
\hline 02 & 02 & 02 & 303 & Gas & 7 & 42 & 56 & 0 & 90 & 300 \\
\hline 06 & 04 & 08 & 888 & Solvents & 0 & 58 & 0 & 0 & 0 & 0 \\
\hline 03 & 01 & 03 & 101 & Charcoal grey & 36 & 82 & 61 & 9 & 88 & 98 \\
\hline 03 & 01 & 03 & 107 & Coke & 98 & 96 & 22 & 9 & 88 & 95 \\
\hline 03 & 01 & 03 & 108 & Coal & 98 & 96 & 22 & 9 & 88 & 95 \\
\hline 03 & 01 & 03 & 111 & Wood & 3 & 98 & 32 & 58 & 94 & 96 \\
\hline 03 & 01 & 03 & 203 & Heavy fuel & 50 & 88 & 3 & 67 & 60 & 60 \\
\hline 03 & 01 & 03 & 204 & Fuel & 50 & 166 & 142 & 240 & 538 & 78 \\
\hline 03 & 01 & 03 & 301 & Natural gas - city gas & 40 & 20 & 24 & 0 & 97 & 140 \\
\hline 03 & 01 & 03 & 303 & Gas & 94 & 36 & 55 & 0 & 90 & 0 \\
\hline \multicolumn{5}{|c|}{ Mean variation per pollutant } & 45 & 109 & 47 & 39 & 102 & 92 \\
\hline
\end{tabular}

of transit traffic (Table 3). Heavy vehicles passing through the tunnel are classified according to their emission levels into four classes, namely euro0, 1, 2 and 3. They are charged fees according to their class.

\subsubsection{Biogenic emissions}

Emissions from vegetation mainly result from biophysical processes such as evapotranspiration. They depend on brightness and temperature. A simple calculation is made over the domain (Eq. (1)), without road gradient effects (Guenther et al., 1996).

$\operatorname{Flux}\left(\mathrm{g} \mathrm{m}^{-2} \mathrm{yr}^{-1}\right)=\varepsilon \cdot D \cdot \Gamma$

where $\varepsilon$ is the average emission potential (emitted mass/vegetation mass/time, $\mathrm{yr}^{-1}$ ) for each particular species, $D$ is the foliar biomass density ( $\mathrm{g}$ dry weight foliage $\mathrm{m}^{-2}$ ), and $\Gamma$ represents the integrated value of

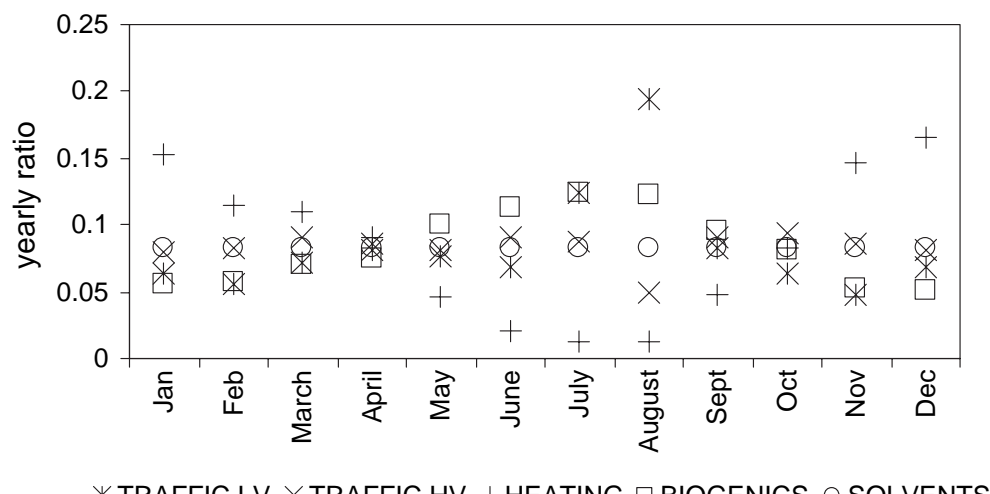

Fig. 4. Time distribution functions relative to traffic, heating, biogenic and solvent emissions. Monthly disintegration coefficient used to calculate temporal distribution of emissions. 


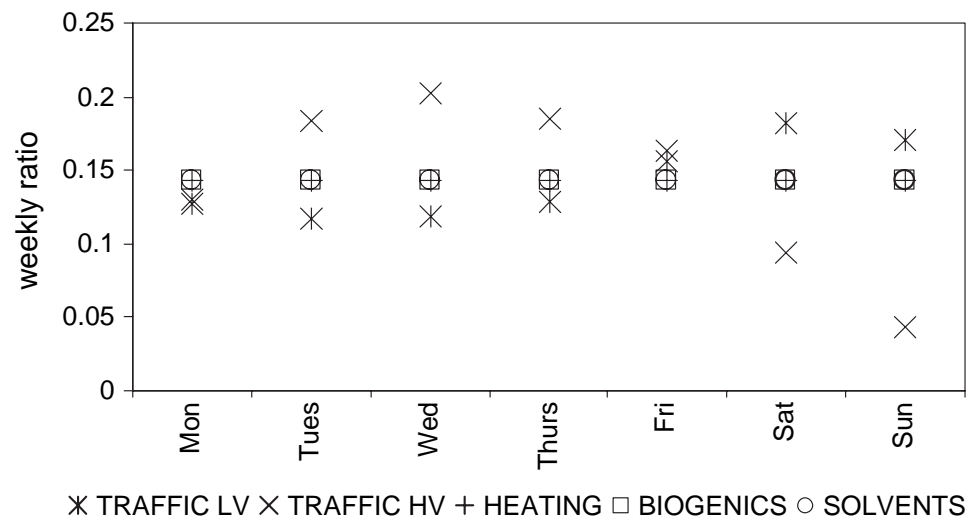

Fig. 5. Time distribution functions relative to traffic, heating, biogenic and solvents emissions. Weekly disintegration coefficient used to calculate temporal distribution of emissions.

a dimensionless environmental correction factor representing the effects of short-term temperature and solar radiation changes in emissions. The real vegetation area $\left(2867 \mathrm{~km}^{2}\right)$ (Fig. 2) is taken into account by making a difference between emissions from deciduous forests, coniferous forests, grassland, tundra and soil. The specific species which are identified in the biogenic emission inventory are: isoprene, monoterpenes, other NMVOC and NO (from soil). The entire methodology is described in the Atmospheric Inventory Guidebook (CORINAIR, 2003).

\subsection{Emission factors}

Emission factors from CORINAIR and BUWALOFEFP are presented in Tables 4 and 5 . They show appreciable differences (Table 6) according to the methodology (CORINAIR, 2003; OFEFP, 1995) and especially for commercial heating (snap 0201 03), residential heating (snap 020202 ), industries (snap 030103 ) and domestic solvents (snap 0604 $02)$. The variation of emission factor values range from $0 \%$ to $538 \%$ (Table 6 ). The greatest variations (on average) are for NMVOC (109\%) and particles $(102 \%)$ and the smallest for $\mathrm{SO}_{2}(39 \%)$ and $\mathrm{NOx}$ $(47 \%)$. Percentages of uncertainty depend on sources and are quite impossible to determine for both methodologies.

\subsection{Temporal disintegration}

Hourly temporal disintegration is carried out in order to provide hourly emissions for the photo-

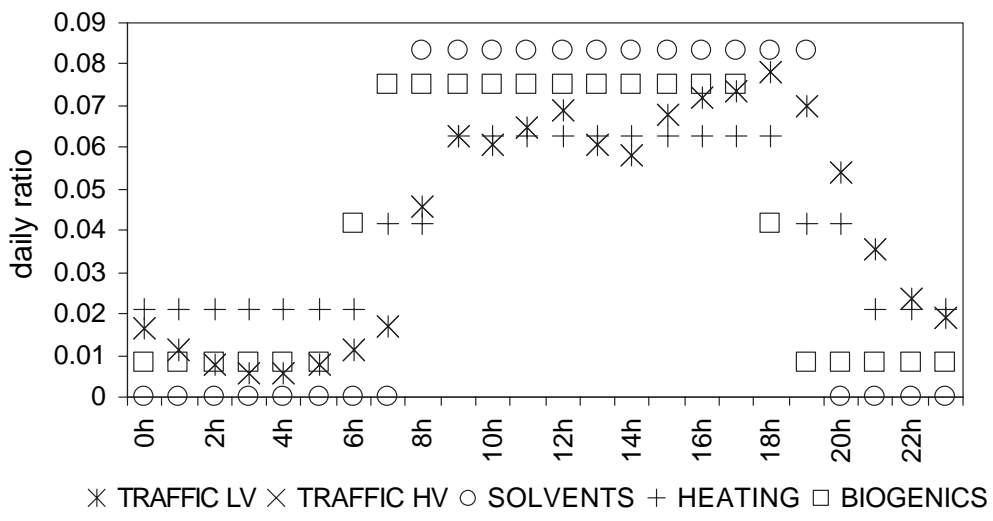

Fig. 6. Time distribution functions relative to traffic, heating, biogenic and solvents emissions. Hourly disintegration coefficient (time is given in $\mathrm{TU})$ used to calculate temporal distribution of emissions. 
Table 7

Biogenic emissions for 2003

\begin{tabular}{lllll}
\hline & Isoprene & Monoterpenes & Other VOC & NO \\
\hline Emission $\left(\mathrm{t} \mathrm{yr}^{-1}\right)$ & 633 & 448 & 853 & 72 \\
\hline
\end{tabular}

chemical model. Hourly time functions (Eq. (2)) were applied to all types of sources.

$E_{\mathrm{h}, \mathrm{i}}=E_{\mathrm{y}, \mathrm{i}} \times M_{\mathrm{k}} \times W_{\mathrm{k}} \times H_{\mathrm{k}}$

With $E_{\mathrm{h}, \mathrm{i}}$ the hourly emitted volume; $E_{\mathrm{y}, \mathrm{i}}$ the yearly volume of pollutant I; $M_{\mathrm{k}}$ the monthly disintegration coefficient; $W_{\mathrm{k}}$ the weekly disintegration coefficient; $H_{\mathrm{k}}$ the hourly disintegration coefficient.

The different disintegration coefficients are detailed in Figs. 4, 5 and 6.

\section{Results of the two emission inventories}

Two different inventories are considered below:

- The emission inventory referred to as inventory A was drawn up using industrial, heating and solvent emission factors from CORINAIR.

- The emission inventory referred to as inventory B was drawn up using industrial, heating and solvent emission factors from OFEFP.

Inventories A and B are based on the same emission inventory for biogenic sources (Table 7 with CORINAIR sources) and road traffic (Table 8) with the use of COPERT III (COPERT III, 2001).

Past comparisons of emission inventories already showed disparities (Seika et al., 1996). Significant differences can be observed in the emission factors from CORINAIR and OFEFP. Variations in the yearly total emissions show differences ranging from $14 \%$ to $95 \%$. The OFEFP emission inventory values are always lower than the CORINAIR values (Tables 9, 10 and 11).

The spatial distribution of the total emissions of $\mathrm{SO}_{2}, \mathrm{NOx}, \mathrm{NMVOC}$ and $\mathrm{CO}$ is presented in Fig. 7.

Table 8

Traffic emissions for 2003

\begin{tabular}{lllllll}
\hline & $\mathrm{CO}$ & NMVOC & $\mathrm{NOx}$ & $\mathrm{SO}_{2}$ & $\mathrm{PM}$ & $\mathrm{CH}_{4}$ \\
\hline Emission $\left(\mathrm{t} \mathrm{yr}^{-1}\right)$ & 7218 & 1009 & 3560 & 90 & 219 & 87 \\
\hline
\end{tabular}

Table 9

Industrial emissions for 2003 with the percentage of variation between CORINAIR and OFEFP values

\begin{tabular}{|c|c|c|c|c|c|c|}
\hline & $\mathrm{CO}$ & NMVOC & NOx & $\mathrm{SO}_{2}$ & PM & $\mathrm{CH}_{4}$ \\
\hline CORINAIR $\left(\mathrm{t} \mathrm{yr}^{-1}\right)$ & 987 & 305 & 590 & 1724 & 895 & 339 \\
\hline OFEFP $\left(\mathrm{t} \mathrm{yr}^{-1}\right)$ & 403 & 18 & 508 & 696 & 75 & 41 \\
\hline Variation (\%) & 59 & 94 & 14 & 60 & 92 & 88 \\
\hline
\end{tabular}

Similar maps could easily be produced for each type of source. In this Fig. 7, the main point sources, roads and urban areas can easily be located. Emissions are concentrated in the bottom of the valley.

\section{Comparison with modelling}

\subsection{Simulation model}

We used a modelling system: numerical simulations combine the mesoscale atmosphere model ARPS 4.5.2 and the troposphere chemistry model TAPOM 1.5.2. This modelling system was improved for the Chamonix valley, where a horizontal resolution of 300 $\mathrm{m}$ was adopted. The meteorological fields from ARPS may be viewed as realistic enough to induce the transport and mixing of the chemical species. The numerical simulation and satisfactory results are detail in (Brulfert et al., 2005; Brulfert, 2004 and Chemel et al., 2004) for both the Chamonix and the Maurienne valleys. The methodology for the Chamonix emission inventory is basically identical but suffered from a lack of data.

\subsubsection{Atmospheric dynamics model}

Large eddy simulation was used to compute mesoscale flow fields. The numerical simulations presented here were run with the Advanced Regional Prediction System (ARPS), version 4.5.2 (Xue et al., 2000,2001 ) with a horizontal resolution of $1 \mathrm{~km}$. Lateral boundary conditions were externally-forced

Table 10

Heating emissions for 2003 with the percentage of variation between CORINAIR and OFEFP values

\begin{tabular}{lrcrrrr}
\hline & $\mathrm{CO}$ & NMVOC & $\mathrm{NOx}$ & $\mathrm{SO}_{2}$ & $\mathrm{PM}$ & $\mathrm{CH}_{4}$ \\
\hline CORINAIR $\left(\mathrm{t} \mathrm{yr}^{-1}\right)$ & 3744 & 107 & 548 & 396 & 78 & 209 \\
OFEFP $\left(\mathrm{t} \mathrm{yr}^{-1}\right)$ & 1973 & 66 & 380 & 285 & 40 & 114 \\
Variation (\%) & 47 & 38 & 30 & 28 & 49 & 45 \\
\hline
\end{tabular}


Table 11

Solvent emissions for 2003 with the percentage of variation between CORINAIR and OFEFP values

\begin{tabular}{lc}
\hline & NMVOC \\
\hline CORINAIR $\left(\mathrm{t} \mathrm{yr}^{-1}\right)$ & 278 \\
OFEFP $\left(\mathrm{t} \mathrm{yr}^{-1}\right)$ & 115 \\
Variation $(\%)$ & 59 \\
\hline
\end{tabular}

from the output of larger-scale simulations performed with the Fifth-Generation Penn State/NCAR Mesoscale Model (MM5 v.3) (Grell et al., 1995).

\subsubsection{Atmosphere chemistry model}

ARPS is coupled off-line with the TAPOM 1.5.2 atmospheric chemistry code (Transport and Air Pollution Model) developed at the LPAS of the EPFLausanne (Clappier, 1998; Gong and Cho, 1993). With 1-km grid cells to calculate dynamics and reactive chemistry, it is possible to represent dynamics in the valley accurately (valley and slope winds) (Anquetin et al., 1999) and to process chemistry at a fine scale.

TAPOM is a three-dimensional eulerian model with terrain following mesh using finite volume discretisation. It includes modules for transport, gaseous and aerosol chemistry, dry deposition and solar radiation. TAPOM uses the Regional Atmospheric Chemistry Modelling (RACM) scheme (Stockwell et al., 1997). The mechanism includes 17 stable inorganic species, 4 inorganic intermediates, 32 stable organic species (four of these are primarily of biogenic origin) and 24 organic intermediates, in 237 reactions. In RACM, the NMVOCs are aggregated into 16 anthropogenic and three biogenic species. Boundary conditions are calculated from CHIMERE, a regional ozone prediction model, from the Institut Pierre Simon Laplace, which gives concentrations of chemical
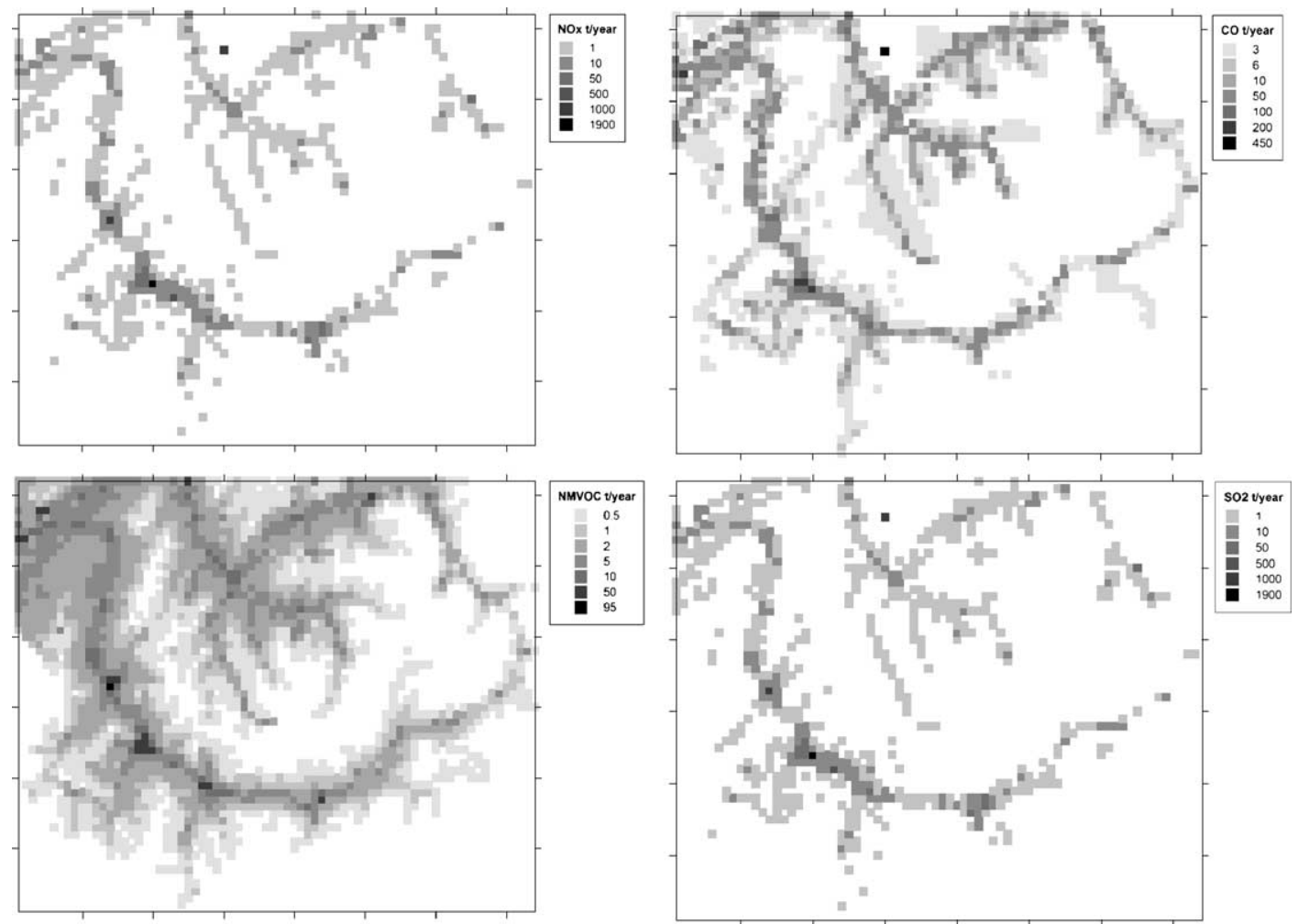

Fig. 7. Spatial distribution of atmospheric emissions (CO, $\left.\mathrm{SO}_{2}, \mathrm{NOx}, \mathrm{NMVOC}\right)$ in the Maurienne valley for 2003 with CORINAIR values (tons per year per $\mathrm{km}^{2}$ ). UTM31 ED50 coordinates are $(745000 ; 4995000)$ for the top left-hand corner and $(819000 ; 5057000)$ for the bottom right corner. 
species at five altitude levels (Schmidt et al., 1998) using its recent multi-scale nested version.

\subsection{NMVOC disintegration for RACM}

The TAPOM model uses the RACM scheme. It includes 32 organic species. The total mass of
NMVOC is disintegrated for this mechanism with coefficients presented in Table 12 (SEDE S.A., 1996). These coefficients depend on the emission sources.

In the case of biogenic emissions, NMVOC consist of isoprene, monoterpenes and other VOC's (described in Table 7). The mass percentage of

Table 12

Disintegration of NMVOC into 32 compounds corresponding to the 32 RACM categories (data in percent of mass of NMVOC)

\begin{tabular}{|c|c|c|c|c|c|c|c|}
\hline & Emission category description & Heating & Solvents & Traffic & Industries & Forest & Grassland \\
\hline 1 & Methane & 0 & 0 & 0 & 0 & 0 & 0 \\
\hline 2 & Ethane & 0 & 0 & 0 & 0 & 0 & 0 \\
\hline 3 & Propane & 0.01 & 0 & 0 & 0 & 0 & 0 \\
\hline 4 & $\begin{array}{l}\text { Alkanes with } \mathrm{OH} \text { rate constant } \\
\text { between } 1.7-3.4 \times 10^{-12} \mathrm{~cm}^{3} \mathrm{~s}^{-1}\end{array}$ & 0.04 & 0 & 0 & 0 & 3.84 & 15.67 \\
\hline 5 & $\begin{array}{l}\text { Alkanes with } \mathrm{OH} \text { rate constant } \\
\text { between } 3.4-6.8 \times 10^{-12} \mathrm{~cm}^{3} \mathrm{~s}^{-1}\end{array}$ & 4.73 & 0 & 3.92 & 5 & 3.84 & 15.67 \\
\hline 6 & $\begin{array}{l}\text { Alkanes with } \mathrm{OH} \text { rate constant } \\
\text { between } 6.8-13.6 \times 10^{-12} \mathrm{~cm}^{3} \mathrm{~s}^{-1}\end{array}$ & 46.37 & 0.17 & 18.37 & 5 & 3.83 & 15.67 \\
\hline 7 & $\begin{array}{l}\text { Alkanes with } \mathrm{OH} \text { rate constant } \\
\text { greater than } 13.6 \times 10^{-12} \mathrm{~cm}^{3} \mathrm{~s}^{-1}\end{array}$ & 0.01 & 0 & 2.72 & 2 & 3.83 & 15.67 \\
\hline 8 & Alkane/aromatic mix & 0 & 0 & 0 & 0 & 0 & 0 \\
\hline 9 & Ethene & 0 & 0 & 0 & 0 & 0 & 0 \\
\hline 10 & Propene & 0 & 0 & 0 & 0 & 0 & 0 \\
\hline 11 & Alkanes (primary) & 0 & 0 & 0 & 0 & 0 & 0 \\
\hline 12 & Alkanes (internal) & 0 & 0 & 0 & 0 & 0 & 0 \\
\hline 13 & Alkanes (primary/internal mix) & 1.73 & 0 & 6 & 0 & 0 & 0 \\
\hline 14 & Benzene, halobenzenes & 0 & 0 & 0 & 0 & 0 & 0 \\
\hline 15 & $\begin{array}{l}\text { Aromatics with } \mathrm{OH} \text { rate constant } \\
\text { less than } 13.6 \times 10^{-12} \mathrm{~cm}^{3} \mathrm{~s}^{-1}\end{array}$ & 8.16 & 0 & 1.74 & 7 & 0 & 0 \\
\hline 16 & $\begin{array}{l}\text { Aromatics with } \mathrm{OH} \text { rate constant } \\
\text { greater than } 13.6 \times 10^{-12} \mathrm{~cm}^{3} \mathrm{~s}^{-1}\end{array}$ & 19.43 & 0.03 & 4.39 & 6 & 0 & 0 \\
\hline 17 & Phenols and cresols & 0 & 0 & 0 & 0 & 0 & 0 \\
\hline 18 & Styrenes & 0 & 0 & 0 & 0 & 0 & 0 \\
\hline 19 & Formaldehyde & 0 & 0 & 0 & 0 & 0 & 0 \\
\hline 20 & Higher aldehydes & 0 & 0 & 0 & 0 & 3.83 & 15.66 \\
\hline 21 & Acetone & 0.01 & 0 & 0 & 4 & 3.83 & 15.66 \\
\hline 22 & Higher ketones & 1.4 & 0 & 0.2 & 4 & 0 & 0 \\
\hline 23 & Organic acids & 0 & 0 & 0 & 0 & 0 & 0 \\
\hline 24 & Acetylene & 0 & 0 & 0 & 0 & 0 & 0 \\
\hline 25 & Haloalkenes & 0.01 & 75.3 & 4.6 & 2.25 & 0 & 0 \\
\hline 26 & Unreactive & 8.32 & 24.5 & 0 & 5 & 0 & 0 \\
\hline 27 & $\begin{array}{l}\text { Others with } \mathrm{HO} \text { rate constant } \\
\text { less than } 1.7 \times 10^{-12} \mathrm{~cm}^{3} \mathrm{~s}^{-1}\end{array}$ & 1.49 & 0 & 2.4 & 23.5 & 0 & 0 \\
\hline 28 & $\begin{array}{l}\text { Others with HO rate constant } \\
\text { betweeen } 1.7-3.4 \times 10^{-12} \mathrm{~cm}^{3} \mathrm{~s}^{-1}\end{array}$ & 0.69 & 0 & 9.16 & 10 & 0 & 0 \\
\hline 29 & $\begin{array}{l}\text { Others with } \mathrm{HO} \text { rate constant } \\
\text { betweeen } 3.4-6.8 \times 10^{-12} \mathrm{~cm}^{3} \mathrm{~s}^{-1}\end{array}$ & 0.27 & 0 & 41.3 & 7 & 0 & 0 \\
\hline 30 & $\begin{array}{l}\text { Others with } \mathrm{HO} \text { rate constant } \\
\text { greater than } 6.8 \times 10^{-12} \mathrm{~cm}^{3} \mathrm{~s}^{-1}\end{array}$ & 0.02 & 0 & 5.4 & 12 & 0 & 0 \\
\hline 31 & Unidentified & 7.31 & 0 & 0 & 0 & 0 & 0 \\
\hline 32 & Unassigned & 0 & 0 & 0 & 7.25 & 0 & 0 \\
\hline
\end{tabular}

Biogenic disintegration is completed with Table 12. 
Table 13

Ratios of isoprene to NMVOC and monoterpenes to NMVOC of biogenic origin

\begin{tabular}{lcc}
\hline & Isoprene/NMVOC & Monoterpenes/NMVOC \\
\hline Forest (\%) & 47 & 30 \\
Grassland (\%) & 0 & 6 \\
\hline
\end{tabular}

isoprene and monoterpenes in the total NMVOC is defined as shown in Table 13 (Hewitt, 1998). In the case of NOx, the distribution is $95 \%$ of $\mathrm{NO}$ and $5 \%$ of $\mathrm{NO}_{2}$ for all classes except biogenic, with only $\mathrm{NO}$ emission from soil.

\subsection{Model results}

Two simulations were performed according to the results of the two inventories (A and $\mathrm{B}$ ) during the summer 2003 intensive period of observations (2430 June), the first (run A) with the CORINAIR inventory (inventory A), and the second (run B) with the OFEFP inventory (inventory B). Runs A and $\mathrm{B}$ differ in terms of the evaluation of domestic and industrial emissions. A and B are based on the same inventory of biogenic sources and road traffic as presented in Table 14.

During this intensive period of observations, several gas measurements were made at different sites along the valley. The measurements of $\mathrm{CO}, \mathrm{NOx}, \mathrm{SO}_{2}$ and $\mathrm{O}_{3}$ may be compared with the model values in order to evaluate the impact of emission factors. Particles are not taken into account at the moment by the model.

Six measurement sites were selected to compare the model and the measurements (Table 15). Comparisons of $\mathrm{CO}, \mathrm{NOx}, \mathrm{SO}_{2}$ and $\mathrm{O}_{3}$ measurements with results from simulations $\mathrm{A}$ and $\mathrm{B}$ are presented in Figs. 8, 9 and 10 from June 24th to

Table 14

Input emission data files for the simulations with emissions from CORINAIR (run A) and from OFEFP (run B)

\begin{tabular}{llll}
\hline & $\begin{array}{l}\text { Common } \\
\text { emission files }\end{array}$ & $\begin{array}{l}\text { CORINAIR } \\
\text { emission files }\end{array}$ & $\begin{array}{l}\text { OFEFP } \\
\text { emission files }\end{array}$ \\
\hline Run A & Traffic, biogenic & $\begin{array}{l}\text { Industries, } \\
\text { solvents, heating }\end{array}$ & $\begin{array}{l}\text { Industries, } \\
\text { solvents, } \\
\text { Run B }\end{array}$ \\
& & heating \\
\hline
\end{tabular}

Table 15

Measurement sites in the Maurienne valley for the summer 2003 intensive period of observations

\begin{tabular}{llccl}
\hline & Latitude & Longitude & $\begin{array}{c}\text { Elevation } \\
\text { (m a.s.l.) }\end{array}$ & Type of site \\
\hline $\begin{array}{l}\text { St Jean de } \\
\quad \text { Maurienne }\end{array}$ & 6.35071 & 45.2757 & 555 & Urban \\
Sollières & 6.8087 & 45.2564 & 1373 & Background \\
Orelle & 6.53735 & 45.2087 & 1134 & Residential \\
St Julien & 6.41225 & 45.2493 & 653 & Traffic \\
Modane & 6.6662 & 45.1965 & 1090 & Urban \\
Arvan valley & 6.31676 & 45.2412 & 820 & Background \\
\hline
\end{tabular}

30th. Results from runs A and B do not differ significantly from one another. This is due to the predominance of traffic emissions with no significant emission from heating in summer.

In the case of $\mathrm{SO}_{2}, \mathrm{NOx}$ and $\mathrm{O}_{3}$, there is a good agreement between the model and the measurements. Measurement sites are representative of the mean pollution in the valley. The discrepancies which are observed in $\mathrm{CO}$ peak values at night (Fig. 10) are induced by inaccuracies in calculating inversion height and should not be attributed to errors in the emission inventory. Anyway these concentrations are weak, since they are 50 times lower than the air quality standard (8591 ppb, on $8 \mathrm{~h}$ ).

In the case of ozone (Fig. 8), both runs give a good agreement with measurements from urban and rural stations. Both the spatial and temporal variability of the simulated ozone concentrations correspond reasonably well with the measured values. The measured (and model) concentrations of $\mathrm{CO}, \mathrm{NOx}, \mathrm{O}_{3}, \mathrm{CO}$ and $\mathrm{SO}_{2}$ are weak compared with air quality standards.

\section{Conclusion}

An atmospheric emission inventory was developed over an alpine area (the Maurienne valley) with a spatial resolution of $1 \mathrm{~km}^{2}$ for the reference year 2003, with the methodology combining bottom-up and topdown reasoning. The area, which covers $4588 \mathrm{~km}^{2}$, is sensitive to emission sources: traffic, industries, heating, domestic solvents, biogenic. During the POVA summer period of intensive observations in 2003, the major sources were road traffic and 
O3 St Jean

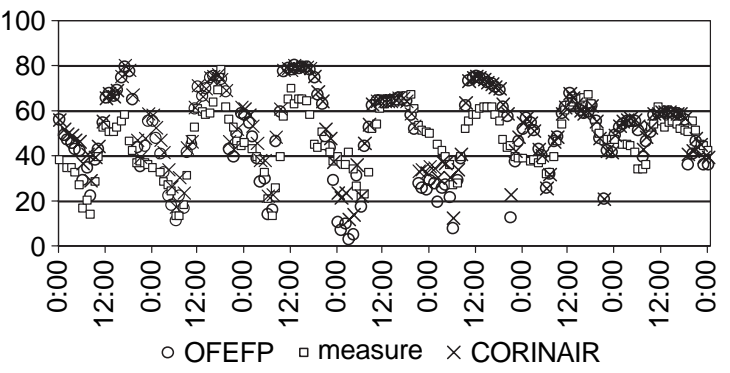

O3 Arvan

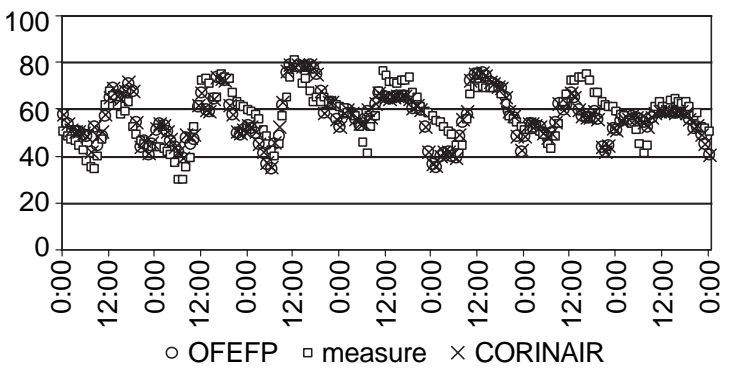

O3 Modane

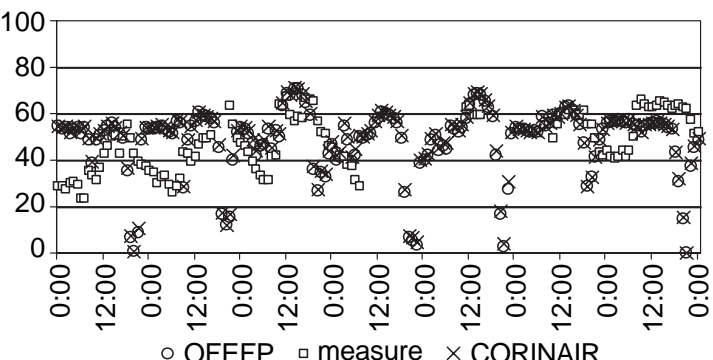

O3 Sollieres

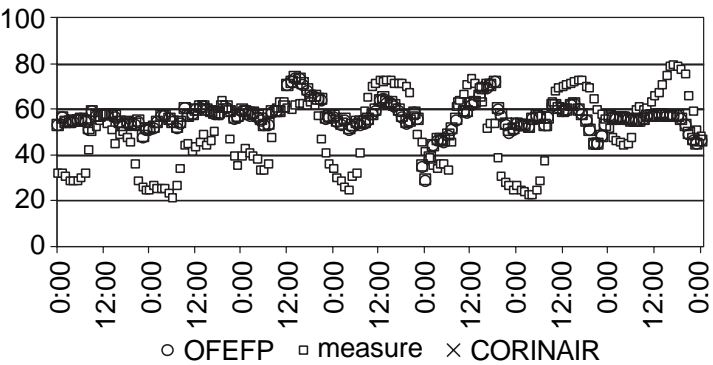

Fig. 8. Ozone concentration [ppbV] in the Maurienne valley, comparison between measurements and results from the model during POVA IOP at two urban sites (St Jean, Modane), and two rural sites (Arvant, Sollières).

NOx St Jean

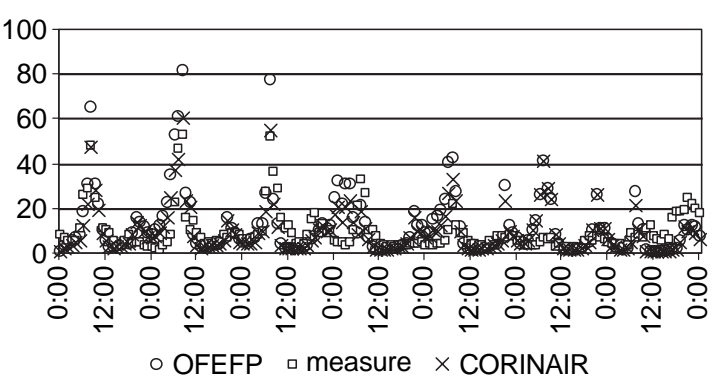

NOx Orelle

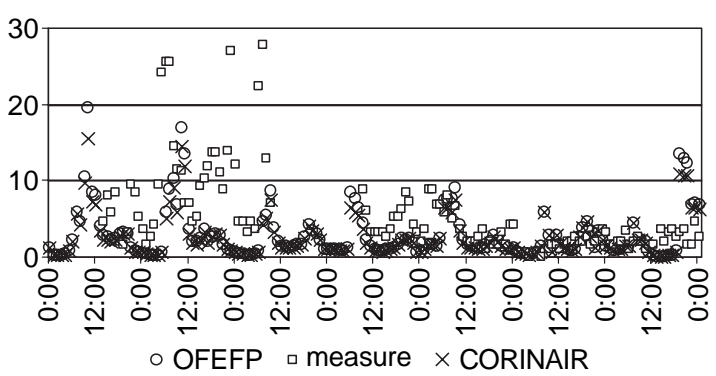

NOx Saint Julien

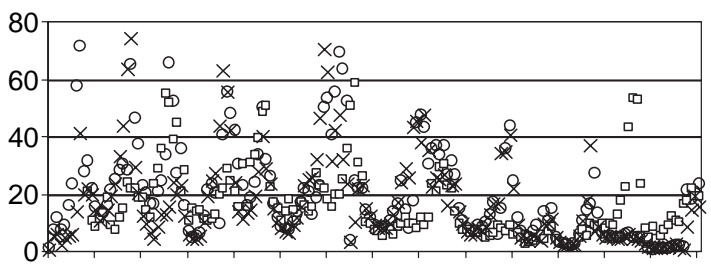

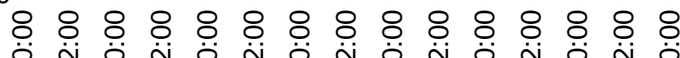
- OFEFP a measure $\times$ CORINAIR

NOx Modane

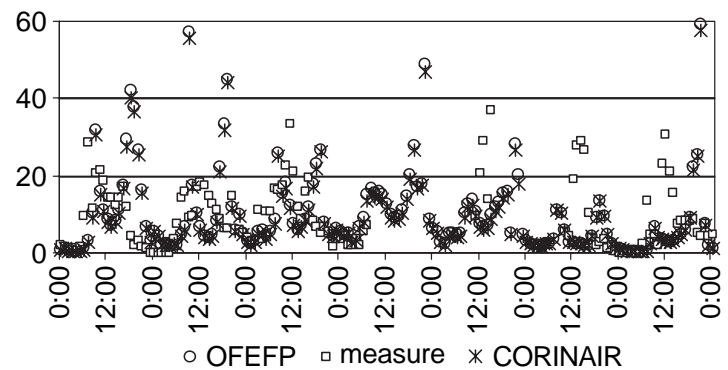

Fig. 9. NOx concentration [ppbV] in the Maurienne valley, comparisons between measurements and model during POVA IOP at four sites (St Jean, St Julien, Orelle, Modane) along the valley. These sites are representative of the highest concentrations in the valley. 
SO2 St Jean

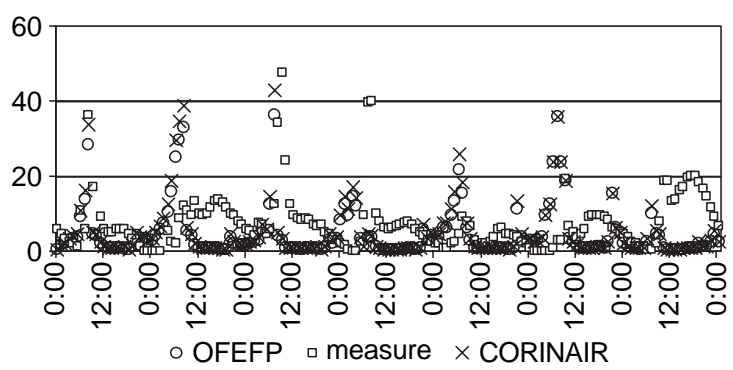

co St Jean

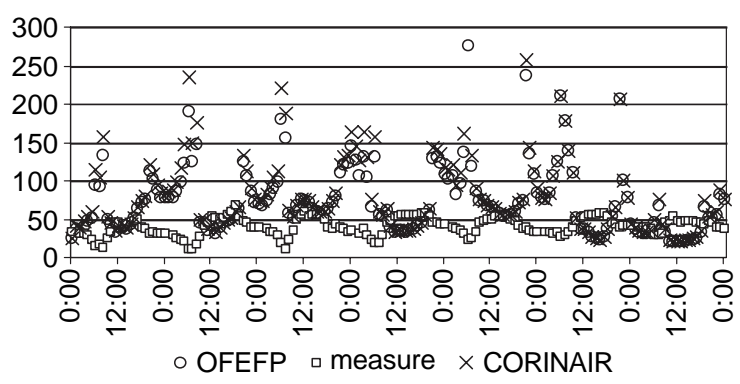

SO2 Saint Julien

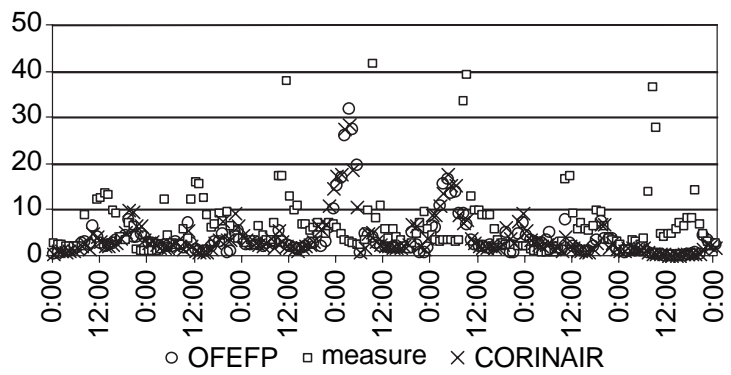

CO Modane

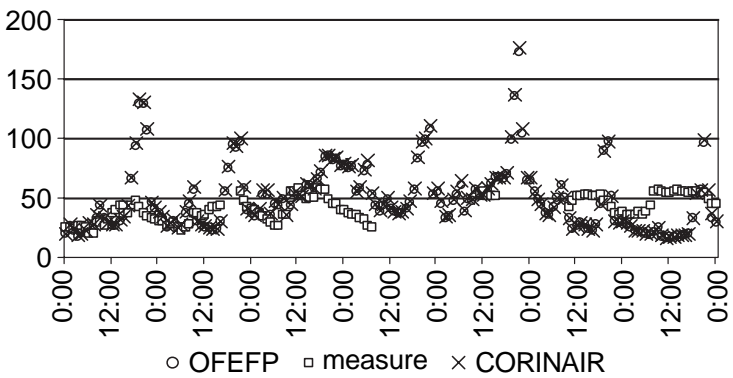

Fig. 10. $\mathrm{SO}_{2}$ and $\mathrm{CO}$ concentrations [ppbV] in the Maurienne valley, comparisons between measurements and model during POVA IOP. St Jean and St Julien sites have major industrial sources for $\mathrm{SO}_{2}$. For $\mathrm{CO}$, St Jean and Modane are two urban sites.

industrial pollution according to the results of the inventory. As expected, the maps of the different major pollutants show significant emissions due mainly to the highway and industries. The emission factors from BUWAL-OFEFP differ from those from CORINAIR. Differences in factor values are up to $538 \%$ and variations in the total emissions, for year 2003 , range from $14 \%$ to $95 \%$.

Several interesting points can be noted: the main pollutant by far (in terms of quantity) is $\mathrm{CO}, 60 \%$ of which results from road traffic, the remaining part being nearly entirely due to domestic heating $(31 \%)$. The road traffic itself is the major source of NOx, VOCs and CO. It represents $75 \%$ of the emissions of $\mathrm{NOx}, 65 \%$ of the anthropogenic emissions of VOC, $28 \%$ of the total VOC emissions (biogenic and anthropogenic). In the case of $\mathrm{SO}_{2}$, the main sources are industrial emissions, which represent $78 \%$ of the total. Biogenic emissions of NMVOCs, which represent $47 \%$ of the total VOC emissions, are far from being negligible and must be taken into account in modelling the atmosphere.
Two simulations were performed with the photochemical model. Both take account of the same traffic and biogenic emission factors. They differ in terms of emissions from industries, heating and solvents. Concentrations computed from the numerical simulation do not show any significant difference and are in agreement with the measurement values. This is due to the preponderance of traffic in summer. Concentrations of $\mathrm{CO}, \mathrm{NOx}, \mathrm{O}_{3}, \mathrm{CO}$ and $\mathrm{SO}_{2}$ are weak compared with air quality standards but nevertheless the values computed from the model remain significant.

By using this emission inventory in the model, specially devoted to alpine valleys, it is now possible in the framework of the POVA project to evaluate the respective impacts of the different types of emission sources and perform scenario studies, particularly with potential changes in international traffic. Future improvements in this inventory will be obtained through comparisons between yearly emissions integrated from this inventory and emissions based on other inventories such as CITEPA (CITEPA, 2004). Individual heat- 
ing is identified as being one of the sources to be better assessed.

\section{Acknowledgements}

Inventories are carried out by the air quality agency 'Air de l'Ain et des Pays de Savoie'. The POVA program is supported by Région Rhône-Alpes, ADEME (French Agency for Environment and Energy Management), METL (French Office for Public Works), MEDD (French Office for Ecology), Primequal2. Meteorological data are provided by Météo France and ECMWF (European Centre for Medium-Range Weather Forecasts), traffic data by SFTRF (Alpine Tunnel of Fréjus), ATMB (Alpine Tunnel of Mont Blanc), DDE (Departmental Directorates of Public Works) of Savoie et Haute-Savoie. Computations were run on Mirage.

\section{References}

Aleksandropoulou V, Lazaridis M. Spatial distribution of gaseous and particulate matter emissions in Greece. Water Air Soil Pollut 2004; 153:15-34.

Anquetin S, Guilbaud C, Chollet JP. Thermal valley inversion impact on the dispersion of a passive polluant in a complex mountainous area. Atmos Environ 1999;33:3953-9.

Bourdeau B. Evolution du parc automobile français entre 1970 et 2020. Thèse de doctorat de l'Université de Savoie; 1998. Rapport LEN n 9801 January 1998.

Brulfert G. Modélisation des circulations atmosphériques pour l'étude de la pollution des vallées alpines. Thesis manuscript. Joseph Fourier University, Grenoble, France; 2004.

Brulfert G, Chemel C, Chaxel E, Chollet JP. Modelling photochemistry in alpine valleys. Submitted to Atmos Chem and Phys Disc 2005; in press.

Chemel C, Chollet JP, Brulfert G, Chaxel E. Evolution of the daytime atmospheric boundary layer structure in a deep alpine valley. Proc of the 16th symposium on boundary layers and turbulence, Portland, ME, Amer. $\sim$ Meteor. $\sim$ Soc [Available on the Amer. Meteor. $\sim$ Soc. website].

CITEPA. French national reference centre on air emissions. http:// www.citepa.org/emissions/index_en.htm.

Clappier A. A correction method for use in multidimensional time splitting advection algorithms: application to two and three dimensional transport. Mon Weather Rev 1998;126:232-42.

Clark TL. Annual anthropogenic pollutant emissions in the United States and southern Canada east of the Rocky Mountains. Atmos Environ 1980;14:961-70.

COPERT III. Computer programme to calculate emissions from road transport, methodology and emission factors (version 21). Leonidas Ntziachristos and Zissis Samaras; 2001.
CORINAIR. EMEP/CORINAIR inventory Guidebook-3rd edition September 2003 update. European Environment Agency; 2003.

Couach O, Balin I, Jiménez R, Ristori R, Kirchner F, Perego S, et al. Investigation of the ozone and planetary boundary layer dynamics on the topographically-complex area of Grenoble by measurements and modeling. Atmos Chem Phys 2003;3: $549-62$.

Cros B, Durand P, Cachier H, Drobinski Ph, Frejafon E, Kottmeier $\mathrm{C}$, et al. The ESCOMPTE program: an overview. Atmos Res 2004;69(3-4):241-79.

Gong W, Cho HR. A numerical scheme for the integration of the gas phase chemical rate equations in three-dimensional atmospheric models. Atmos Environ 1993;27A(14):2147-60.

Grell GA, Dudhia J, Stauffer DR. A description of the fifthgeneration Penn State/NCAR Mesoscale Model (MM5). NCAR Technical note NCAR/TN-398+STR. Boulder, CO: National Center for Atmospheric Research; 1994. 125 pp. Available on the web at: http://www.mmm.ucar.edu/mm5/docl.html.

Guenther A, Greenberg J, Helmig D, Klinger L, Vierling L, Zimmerman P, et al. Leaf, branch, stand and landscape scale measurements of volatile organic compound fluxes from US woodlands. Tree Physiol 1996;16:17-24.

Hewitt NC. Reactive hydrocarbons in the atmosphere, Lancaster Institute of Environmental and Natural Sciences. Lancaster University; 1998.

INSEE. Census of the population by the French National Institute of Statistics and Economic Studies. http://www.recensement. insee.fr/.

Jaffrezo JL, Albinet A, Aymoz G, Besombes JL, Bonsang B, Brulfert G, et al. The program POVA "Pollution des Vallées Alpines": general presentation and some highlights. Submitted to Atmos Chem Phys 2005.

Khatami A, Ponche JL, Jabry E, Mirabel Ph. The air quality management of the region of Great Casablanca (Morocco): Part 1. Atmospheric emission inventory for the year 1992. Sci Total Environ 1998;209:201-16.

Lamb B, Guenther A, Gay D, Westberg H. A national inventory of biogenic hydrocarbon emissions. Atmos Environ 1987;21: $1695-705$.

Lamb B, Gay D, Westberg H. A biogenic hydrocarbon emission inventory for the USA using a simple forest canopy model. Atmos Environ 1993;11:1673-90.

Lenhart L, Friedrich R. European emission data with high temporal and spatial resolution. Water Air Soil Pollut 1995;85:1897-902.

OECD. (Organisation for the European Cooperation and Development). Summary record of the workshop on emission inventories in Appeldoorn, 27-28 Sept 1984. ENV/AIR/M 8410; 1990.

OFEFP. Emissions polluantes dues à l'activité humaine en Suisse de 1900 à 2010. Cahier de l'environnement $\mathrm{n}^{\circ}$ 256-Air. Berne: Publié par l'Office fédéral de l'environnement, des forêts et du paysage (OFEFP); 1995.

Ponche JL. Emissions dans l'atmosphère dues au trafic routier et dues aux sources ponctuelles. Internal REKLIP report $\mathrm{n}^{\circ} 2$, LPCA-CGS Strasbourg (F) 1992; 1992.

Ponche JL, Schneider C, Mirabel Ph. Réalisation du cadastre des émissions atmosphériques pour l'Alsace dans le cadre du projet 
climatologique régional REKLIP. Publications de l'Association Internationale de Climatologie 1993;6:659-71.

Ponche JL, Ghannouchi R, Oudin V, Mirabel Ph. The FrenchGerman emission inventory for the urban community of Strasbourg-Ortenau ward (Kehl-Offenburg). Pollut Atmos 1995; 148:77-88.

Ponche JL, Zaïdi N, Fayet S, Mirabel Ph. L'inventaire spatialisé des émissions atmosphériques pour la Région de Strasbourg (Communauté Urbaine de Strasbourg étendue). Pollut Atmos 1998;159:64-72.

Ponche JL, Schneider C, Mirabel P. Methodology and results of the REKLIP atmospheric emission inventory of the upper Rhine valley transborder region. Water Air Soil Pollut 2000; 124:61-93.

SEDE SA. Etablissement d'un cadastre d'émissions sur la région genevoise, projet COST 615; 1996.

Schmidt H, Derognat C, Vautard R, Beekmann M. A comparison of simulated and observed ozone mixing ratios for the summer of 1998 in Western Europe. Atmos Environ 2001;35:6277-97.

Seika M, Metz N, Harrison RM. Characteristics of urban and state emission inventories - a comparison of examples from Europe and the United States. Sci Total Environ 1996;189-190:221-34.
Stockwell R, Kirchner F, Kuhn M, Seefeld S. A new mechanism for atmospheric chemistry modelling. J Geophys Res 1997; 102(D22):25847-79.

Sturm P, Study C, Almbauer R, Meinhart J. Updated urban emission inventory with a high resolution in time and space for the city of Graz. Sci Total Environ 1999;235:111-8.

Veldt C. Emissions of SOX, NOX, VOC and CO from East European Countries. Atmos Environ 1991;25A:2683-700.

Voldner EC, Shah Y, Whelpdale DM. A preliminary Canadian emissions inventory for sulphur and nitrogen oxides. Atmos Environ 1980;14:419-28.

Xue M, Droegemeir V, Wong V. The Advanced Regional Prediction System (ARPS) - a multi-scale nonhydrostatic atmospheric simulation and prediction model: Part I. Model dynamics and verification. Meteorol Atmos Phys 2000;75(3/4):161-93.

Xue M, Droegemeir KK, Wong V, Shapiro A, Brewster K, Carr F, et al. The Advanced Regional Prediction System (ARPS)-a multi-scale non hydrostatic atmospheric simulation and prediction tool: Part II. Model physics and applications. Meteorol Atmos Phys 2001;76:143-65. 